\title{
Material Cost Model for Innovative Li-lon Battery Cells in Electric Vehicle Applications
}

\author{
Ralf Petri',, Tobias Giebel', Bin Zhang', Jan-Hinnerk Schünemann', and Christoph Herrmann² \\ 1 VOLKSWAGEN AG, Berliner Ring 2, 38440 Wolfsburg, Germany \\ 2 Institute for Machine Tools and Production Technology, Technische Universität Braunschweig, Langer Kamp 19 B, 38106 Braunschweig, Germany \\ \# Corresponding Author / E-mail: ralf.petri87@t-online.de, TEL: +49-5361-9-73217, FAX: +49-5361-957-24543
}

KEYWORDS: Forecasting cost model, Material costs li-ion battery, Li-lon battery performances, Electric mobility

\begin{abstract}
Due to global warming and the rise of the $\mathrm{CO}_{2}$ emissions electric mobility is in the focus. In this case costs for li-ion batteries and especially the material costs are the main cost drivers for electric vehicles. The aim of this paper is to develop a material cost model which can evaluate cell chemistry alternatives for li-ion battery anodes and cathodes. A focus is set on innovative cell chemistries which currently are not using in mass production. The presented model is based on bottom-up approach which can calculate costs and cell performance together to determine the ratio of material cost and energy. The general results are complemented with a case study that assesses that active material with a high specific energy can help reducing the material costs and improves cell performance parameters.
\end{abstract}

\section{NOMENCLATURE}

$A=$ surface of the electrode-separator-layer-package per cell

$\mathrm{a}_{\mathrm{p}}=$ passive material part

$\mathrm{C}=$ capacity of the cell

$\mathrm{c}_{\text {spec }}=$ specific capacity of the active material

$\mathrm{E}=$ energy of the cell

$\mathrm{h}_{\mathrm{A}+\mathrm{P}}=$ solid content electrode film

$\mathrm{KB}=$ electrode loading

$\mathrm{M}_{\mathrm{k}}=$ mass cathode active film

$\mathrm{p}_{\text {active }}=$ true density active material

$\mathrm{p}_{\text {passive }}=$ true density passive material

$\mathrm{U}=$ nominal voltage of the cell

$\mathrm{u}_{\mathrm{a}}=$ potential anode active material

$\mathrm{u}_{\mathrm{k}}=$ potential cathode active material

$\mathrm{V}_{\mathrm{i}}=$ inner cell volume

$\varphi=$ filling factor

$\mathrm{Z}=$ thickness of the electrode-separator-layer-package

$\mathrm{Z}_{\mathrm{a}}=$ anode film thickness

$\mathrm{Z}_{\mathrm{e}}=$ electrode film thickness

$\mathrm{zk}=$ cathode film thickness

$\mathrm{Z}_{\mathrm{ka}}=$ collector thickness anode

$$
\begin{aligned}
& \mathrm{Z}_{\mathrm{kk}}=\text { collector thickness cathode } \\
& \mathrm{z}_{\mathrm{sep}}=\text { separator thickness }
\end{aligned}
$$

\section{Introduction}

Due to global warming and the rise of $\mathrm{CO}_{2}$ emissions electric mobility came to the societal focus. The success of electric mobility depends significantly on several forces. ${ }^{1,2}$ Besides the environment, the customer, politics, and competition, costs are a substantial factor in the future enforcement. ${ }^{3}$

The main cost driver is the li-ion battery because during the production process there is a huge demand of expensive rare earths like cobalt, nickel or lithium. The material cost share lies between 55-75\% of the cost of sales. ${ }^{4-7}$

Further investigation is required due to the high material costs.

\section{State of the Art}

\subsection{Requirements}


Currently, there are different types of cost models to describe the cost structure and performances of li-ion batteries in electric vehicle (EV) applications. Concerning this background the paper will give an overview about strengths and weaknesses of cost models described in literature. To compare cost models literature holds different criterions, a short selection is presented below: ${ }^{8-10}$

- Generality: Generality is defined as the quality of being universal. In this case it means that the cost models can calculate a broad range of lithium ion batteries.

- Transparency: Transparency is an important condition for a free exchange and for the validation later on.

- Validation: Validation is the procedure to proof that the cost model fulfills its intended purpose.

- Availability: Availability describes the access a user gets to receive the cost model.

The presented criteria will be used for benchmarking hereupon.

\subsection{Li-Ion Battery Cost Models in Literature}

\subsubsection{Base Cell Model}

In 2000 Gaines and Cuenca published a cost model for li-ion batteries for EV applications to describe the cost structure and the development for different future scenarios. To estimate the material costs Gaines and Cuenca analyze the historical price developments of various rare materials and build development scenarios using this knowledge. Within these scenarios the authors show the effects on their material cost structure during material price changes. ${ }^{11}$

\subsubsection{Battery Weight Model}

The focus of the model lies on the material costs of li-ion batteries for EV applications, the authors Amirault et al. assume that the material cost share makes up $75 \%$ of the cost of sales. Therefore the production costs will not be calculated. With the aid of energy and power requirements the model deduces battery weights and cell chemistries for three different car classifications (Sports, Sedan and SUV). After that the masses will be multiplied with specific cost rates to estimate the battery costs. ${ }^{12}$

\subsubsection{Battery Performance and Cost Model}

The "BatPaC" model of Nelson et al. calculates also different performance parameters like energy or power in addition to the costs of different li-ion batteries. The procedure of the model is "bottom-up", which means that the model estimates costs and performance parameters together on the base of individual components (cathode, anode, electrolyte, separator e.g.). Subsequently the model is capable to estimate cost and performance parameters with a high forecast quality. ${ }^{13}$

\subsubsection{Valuation of the Models}

Owing to the use of "base" cells the model of Gaines and Cuenca does not allow to calculate material costs for innovative li-ion batteries with other performances. The point "generality" is a weakness. Furthermore, Gaines and Cuenca have not published the cost model structure, so "transparency" and "validation" are less pronounced.

In the context of the "Battery Weight Model" the estimation of the specific cost rates will not be depicted, Amirault et al. are only giving reference on general literature, so the points "transparency" and "validation" are not succeeded. Also the model structure is not published, and so there is no possibility to calculate innovative cell chemistries or other li-ion battery types. Therefore the point "generality" is not fully succeeded.

The "BatPaC" model of Nelson et al. is available for free on the internet with an extensive bundle of documentation, so the points "Generality", "Transparency", "Validation" and "Availability" can classify as strengths. However, the disadvantage is that a simple material cost forecasting calculation with a minimum of input parameters is not in focus. Nelson et al. indicate a forecast quality for material costs in the field of $\pm 10 \%$. ${ }^{13,14}$

Table 1 summarizes the advantages and disadvantages of the shown li-ion cost models.

In the view of material costs and especially cost-energy ratio calculation, the "BatPaC" model of Nelson et al. fulfill the criteria on the contrary to the other models most suitable with the disadvantage of the high calculation complexity (many input parameters). The "Base Cell Model" and the "Battery Weight Model" have in common that there is no possibility to calculate different cell chemicals and showing their effects on material cost as well as cell parameters. Therefore a new model approach will be presented in this paper. The model is easy to use with a minimum of input parameters and allows to determine the important cost-energy ratio for current and innovative cell chemistries. ${ }^{15}$

\section{Methodology}

\subsection{Overview of the Material Cost Model Structure}

Fig. 1 gives an overview of the whole material cost model structure with the main input and output parameters.

The first step includes the choice of the cell chemistries for anode and cathode. After the choice of the cell chemistries the next step includes the calculation of the electrodes, especially "electrode press density" and "electrode layer thickness" which will be used later for affirmative the cell performances parameters (especially energy and

Table 1 Advantages and disadvantages of different li-ion battery cost models

\begin{tabular}{lccc}
\hline & $\begin{array}{c}\text { Gaines/Cuenca } \\
(2000)\end{array}$ & $\begin{array}{c}\text { Amirault et al. } \\
(2009)\end{array}$ & $\begin{array}{c}\text { Nelson et al. } \\
(2012)\end{array}$ \\
\hline Classification & $\begin{array}{c}\text { "Base cell" } \\
\text { based }\end{array}$ & $\begin{array}{c}\text { "Weight" } \\
\text { based }\end{array}$ & $\begin{array}{c}\text { "Performance" } \\
\text { based }\end{array}$ \\
\hline Generality & $\bigcirc$ & 0 & 0 \\
\hline Transparency & $\bigcirc$ & 0 & 0 \\
\hline \multicolumn{1}{c}{ Validation } & $\bigcirc$ & 0 & 0 \\
\hline Availability & $\bigcirc$ & 0 & 0 \\
\hline Advantage & & & \\
Neutral & & & \\
Disadvantage & & &
\end{tabular}

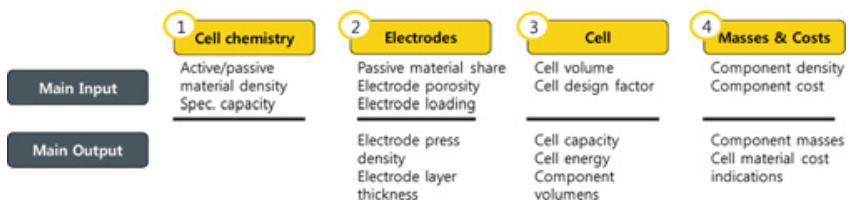

Fig. 1 Structure and main steps of the material cost model 
capacity) and material costs. For that reason the presented model can classified as "cell chemical based".

\subsection{Conception in Detail}

The model comprises of the basic idea that a current or innovative, limited active volume is available in every cell format. The area of the cell, which is filled by the jelly roll, consisting of cathode, anode and separator, qualifies as active volume and is thereby determining the capacity and energy, compare Fig. 2.

The active volume determines itself through the inner cell volume on one hand and the limitations, which result from the design and the passive structures (deflector, terminals e.g.) on the other hand. As an abstract of the principal idea an "electrode-separator-layer package", is introduced, that describes the active volume of a li-ion battery. The "electrode-separator-layer package" contains two separators (white), one double sided anode (black), one anode collector (copper), one double sided cathode (red) and one cathode collector (silver), compare Figs. 2 and 3. The second separator within the "electrode-separatorlayer package" enables the "electrode-separator-layer package" to be arbitrarily stackable to show the active volume this way. The determination of the mass takes place with the aid of the total panel of the "electrode-separator-layer package" per cell and the resulting single panel for anode, cathode, separator and collectors, as well as the related individual density of the used materials, compare Fig. 3.

\subsubsection{Determination of the Component Mass Based on the Cathode Film}

The electrode-separator-layer package is the central point in the

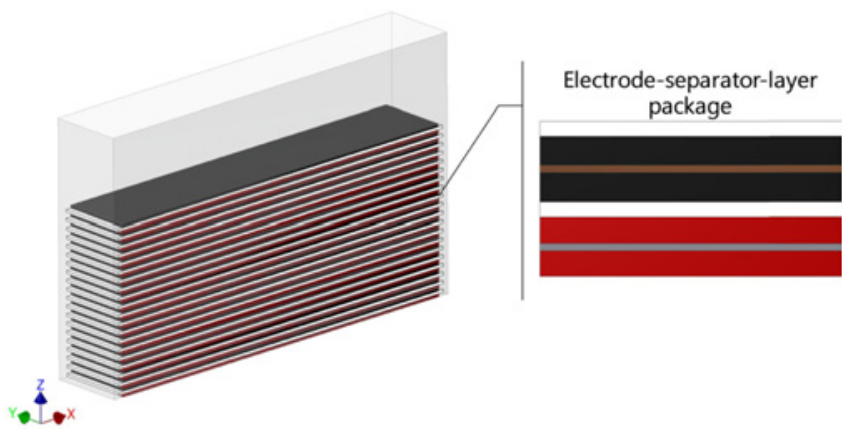

Fig. 2 Abstraction of a li-ion battery cell (PHEV2 format example)

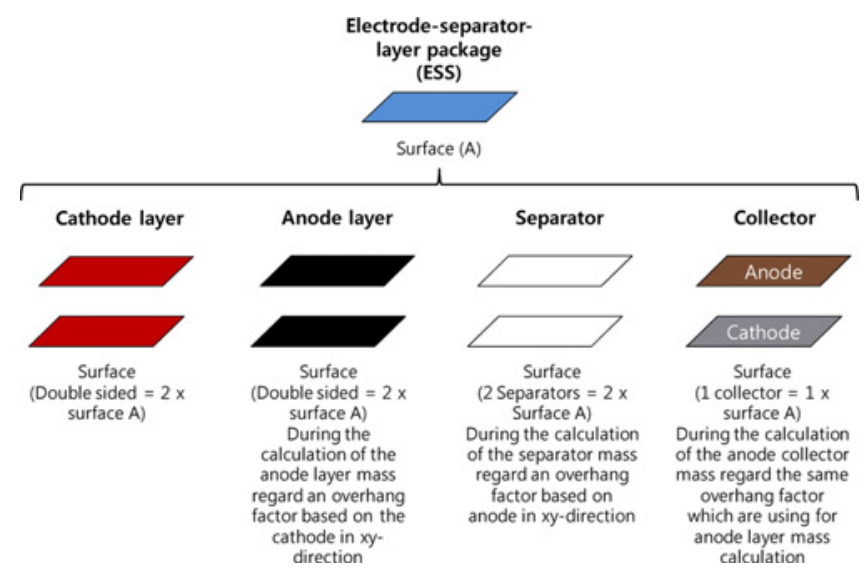

Fig. 3 Layers of the electrode-separator-layer package in detail development of the component mass model. This theoretic construct does not only determine the electrical cell performances, but also the individual component masses, which are eventually assessed monetarily. Following the determination is exemplary demonstrated with the example of the cathode film.

The abstract fits into every li-ion battery with the associated active volume and a certain amount of electrode-separator-layer packages. The electrode-separator-layer package is determined geometrically in the $\mathrm{x}-, \mathrm{y}-, \mathrm{z}$-direction through the selected electrode loading of the electrode films as well as the collector- and separator dimensions. Before calculating the quantity and thereby the active area, the geometrical dimensions of the electrode films have to be identified.

Fig. 4 shows a double sided coated electrode band and an electrode film in full section. The electrode film consists of air $(L)$, which is found in the pores, of active material $(A)$ and of passive material $(P)$, as you can see in Fig. 4. After calendering the electrode film is highly condensed. Ideally porosity only exists within the electrode film itself, previously described as air $(L)$, and there is no more porosity anymore between the single active and passive material portions and their crystalline structures, which are called true density or skeleton density $\left(p_{\text {active }} p_{\text {passive }}\right)$. It can be therefore assumed that the active- and passive material portions consist of one particle each, which is called monoparticular, see picture "electrode film abstract" in Fig. 4 for further information.

For calculating the li-ion battery cell and therefore to determine the thickness of the electrode film, the desired electrode loading $(K B)$ is considered. Depending on the design of the li-ion battery cell regarding "High Power" or "High Energy", the electrode loading is set to a value between $1.5-3.0 \mathrm{mAhcm}^{-2} .{ }^{16,17}$ For the description of the electrode film thickness a construct has to be created that describes the proportions of the coating thickness to each other and to the total film thickness $\left(z_{e}\right)$ :

$$
z_{e}=\frac{K B}{c_{\text {spec }} \cdot h_{A+P} \cdot\left(\frac{\frac{1-a_{p}}{p_{\text {active }}}}{\frac{1-a_{p}}{p_{\text {active }}}+\frac{a_{p}}{p_{\text {passive }}}}\right) \cdot p_{\text {active }}}
$$

The term in brackets reflects the relation of the different layer thicknesses to each other. The result of the term is ideally regarded as single particular and is thus multiplied with the true density of the active material. Finally the electrode film thickness from the selected electrode loading arises as a result, as shown. The electrode film thickness is geometrically ascertainable, depending on the electrode loading. The formula is adaptable for the anode- and cathode film. When calculating the same electrode loading is used for the anode film as previously used for the cathode film. The anode film has to be capacitive over dimensioned in comparison to the cathode film for functional reasons. ${ }^{17,18}$

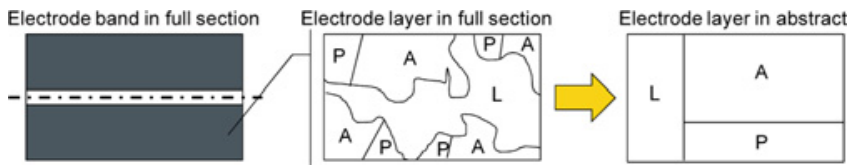

Fig. 4 Electrode band and -film in full section 


\subsubsection{Total Thickness Determination of the Electrode-Separator-} Layer-Package

The total thickness of the electrode-separator-layer-package $(Z)$ can be defined through the thickness of the collector $\left(z_{k k} ; z_{k a}\right)$, the separator thickness $\left(z_{\text {sep }}\right)$ and the electrode film thickness $\left(z_{k} ; z_{a}\right)$ into z-direction (see Fig. 2). The thicknesses for the collectors, as well as for the separator, can be individually specified depending on application. The total thickness of the electrode-separator-layer-package is described through:

$$
Z=z_{k k}+z_{k a}+2 \cdot\left(z_{\text {sep }}+z_{k}+z_{a}\right)
$$

\subsubsection{Determining the Total Area of the Electrode-Separator- Layer-Package}

Following formula describes the fact that through the number of electrode-separator-layer-packages the active volume $\left(V_{i} \cdot \varphi\right)$ of an arbitrary li-ion battery cell can be transformed into an area $(A)$ and is thus assessable:

$$
A=\frac{V_{i} \cdot \varphi}{Z}
$$

For the determination of the filling factor $(\varphi)$ empirical investigations, depending on the cell format, have to be conducted.

\subsubsection{Determining the Component Mass of the Cathode Film}

The mass for the cathode film $\left(M_{k}\right)$ is the product of the true density of the active material, the thickness of the film and the single area within the electrode-separator-layer-package. Due to the double sided coating, Factor 2 is used for multiplication:

$$
M_{k}=p_{\text {active }} \cdot z_{k} \cdot A \cdot 2
$$

When calculating the mass for the cathode film it has to be noted that the thickness of the film results as well from passive materials. For simplification the passive material part is treated as active material in the calculation and not issued separately. This leads to higher masses and costs for the components "cathode-/anode film" in later course, because active materials are usually more dense and more expensive than passive materials. In this case the circumstance can be neglected because of the low percentile part of the passive material.

\subsubsection{Determination of the Electric Cell Performances}

Since every electrode-separator-layer-package consists of a double sided anode and cathode and is therefore building capacity and energy, the capacity $(C)$ is determined through the total capacity area and its electrode loading within the li-ion battery cell. Due to the double sided coating, Factor 2 is used for multiplication:

$$
C=K B \cdot A \cdot 2
$$

The energy from a li-ion battery cell is the product of capacity and nominal voltage $(U)$. Nominal voltage results from the average value between the potential of the cathode and the potential of the anode:

$$
U=u_{k}-u_{a}
$$

Following Energy $(E)$ results from this:

$$
E=U \cdot C
$$

\subsection{Validation}

For validating the introduced methodology the information for Sanyo PHEV 28 Ah from the report "IIT LIB-related Study Program $10-11$ " is used. ${ }^{6}$ Further specific details considering the active materials or the cell designs can be taken from relevant literature. ${ }^{17,19}$

An extensive validation with a VOLKSWAGEN VARTA MICROBATTERY 2,1 Ah 18650 and 37 Ah PHEV2 example as well as the complete material cost methodology with different application examples has been performed. ${ }^{20}$ Table 3 shows the deviation to the reference cells.

As shown in Tables 2 and 3 the prognosis rating for the components and the performance parameters is $+17 \%$ at the highest. For the two in detail presented VOLKSWAGEN VARTA Microbattery cells the forecast quality for the main parameters "energy" and "cost-energy ratio" is $\pm 3 \%$. According to Arago referring to the VDI guideline 2225 a accuracy of $\pm 10 \%$ is seen as a "good" result. ${ }^{20,21}$ As a result valid statements can be made concerning the component masses, the costs as well as the electric cell performances.

\subsection{Case Study: Cell Chemical Alternatives}

The model is also used on the Sanyo PHEV 28 Ah cell. Besides the

Table 2 Validation using Sanyo PHEV 28 Ah as example

\begin{tabular}{cccc}
\hline $\begin{array}{c}\text { Component/ } \\
\text { Performance } \\
\text { parameter }\end{array}$ & Model & Reference & Deviation \\
\hline Anode C & $135.3 \mathrm{~g}$ & $146.1 \mathrm{~g}$ & $-7.4 \%$ \\
\hline Cathode NMC & $192.4 \mathrm{~g}$ & $193.1 \mathrm{~g}$ & $0.0 \%$ \\
\hline Capacity & $25.2 \mathrm{Ah}$ & $28 \mathrm{Ah}$ & $-10.0 \%$ \\
\hline Voltage & $3.7 \mathrm{~V}$ & $3.7 \mathrm{~V}$ & $0.0 \%$ \\
\hline Energy & $93.2 \mathrm{Wh}$ & $103.6 \mathrm{Wh}$ & $-10.0 \%$ \\
\hline
\end{tabular}

Table 3 Detailed validation using VOLKSWAGEN VARTA MICROBATTERY 2,1 Ah 18650 and 36 Ah PHEV2 as examples ${ }^{20}$

\begin{tabular}{ccc}
\hline $\begin{array}{c}\text { Component/ } \\
\text { Performance parameter }\end{array}$ & $\begin{array}{c}18650 \\
\text { Deviation } \\
{[\%]}\end{array}$ & $\begin{array}{c}\text { PHEV2 } \\
\text { Deviation } \\
{[\%]}\end{array}$ \\
\hline Cathode film density & -4 & -4 \\
\hline Anode film density & 0 & -2 \\
\hline $\begin{array}{c}\text { Thickness of cathode } \\
\text { layer }\end{array}$ & +10 & -3 \\
\hline Thickness of anode layer & 0 & -7 \\
\hline Cathode film mass & +4 & -8 \\
\hline Anode film mass & -7 & -9 \\
\hline Cathode collector mass & +17 & +4 \\
\hline Anode collector mass & +2 & +17 \\
\hline Separator mass & -4 & -10 \\
\hline Electrolyte mass & -1 & +13 \\
\hline Capacity & -2 & +3 \\
\hline Voltage & 0 & 0 \\
\hline Energy & -1 & 0 \\
\hline Material costs & 0 & +2 \\
\hline Cost-Energy ration & -1 & +3 \\
\hline
\end{tabular}


original cell chemistry $\mathrm{C} / \mathrm{NMC}$, the cell chemistries $\mathrm{C} / \mathrm{LFP}, \mathrm{C} / \mathrm{LMO}, \mathrm{C} /$ Li-rich NMC and Si-composite/Li-rich NMC are used in this frame. Following additional input parameters are being used:

Further specifications for modeling are:

- The density of the passive materials is not varied in the different cell chemistries.

- The electrode loading, the porosity of the electrodes together with the other components (collectors, separator etc.) stay constant for comparison

Fig. 5 shows the results of the model application. This Fig. is normalized to the basic cell chemistry of $\mathrm{C} / \mathrm{NMC}$. Left from it you can find the current cell chemistry alternatives $\mathrm{C} / \mathrm{LFP}$ as well as $\mathrm{C} / \mathrm{LMO}$ and on the right side you can see the innovative ones, $\mathrm{C} / \mathrm{Li}$-rich and Si-composite/Li-rich. Currently the innovative cell chemistries are not commercially applied, therefore the active material cost is taken from studies or estimated.

As visible C/LMO has the best material cost-energy ratio of the

Table 4 Further input parameters ${ }^{6,22-28}$

\begin{tabular}{|c|c|c|}
\hline Component & Price & Others \\
\hline NMC & 20,68 EURkg-1 & $\begin{array}{c}\mathrm{c}=150 \mathrm{mAhg}^{-1} ; \mathrm{p}_{\text {active }}=4,75 \mathrm{gcm}^{-3} ; \\
\mathrm{a}_{\mathrm{p}}=6 \% ; \mathrm{u}_{\mathrm{k}}=3,7 \mathrm{~V} ; \\
\mathrm{p}_{\mathrm{e}}=30 \%\end{array}$ \\
\hline LFP & 11,36 EURkg-1 & $\begin{array}{c}\mathrm{c}=160 \mathrm{mAhg}^{-1} ; \mathrm{p}_{\text {active }}=3,36 \mathrm{gcm}^{-3} ; \\
\mathrm{a}_{\mathrm{p}}=12 \% ; \mathrm{u}_{\mathrm{k}}=3,5 \mathrm{~V} ; \\
\mathrm{p}_{\mathrm{e}}=30 \%\end{array}$ \\
\hline LMO & 11,43 EURkg ${ }^{-1}$ & $\begin{array}{c}\mathrm{c}=120 \mathrm{mAhg}^{-1} ; \mathrm{p}_{\text {active }}=4,80 \mathrm{gcm}^{-3} ; \\
\mathrm{a}_{\mathrm{p}}=6 \% ; \mathrm{u}_{\mathrm{k}}=4,0 \mathrm{~V} ; \\
\mathrm{p}_{\mathrm{e}}=30 \%\end{array}$ \\
\hline Li-rich NMC & 16,52 EURkg $^{-1}$ & $\begin{array}{c}\mathrm{c}=220 \mathrm{mAhg}^{-1} ; \mathrm{p}_{\text {active }}=4,60 \mathrm{gcm}^{-3} ; \\
\mathrm{a}_{\mathrm{p}}=6 \% ; \mathrm{u}_{\mathrm{k}}=3,8 \mathrm{~V} ; \\
\mathrm{p}_{\mathrm{e}}=30 \%\end{array}$ \\
\hline $\mathrm{C}$ & 9,43 EURkg ${ }^{-1}$ & $\begin{array}{c}\mathrm{c}=360 \mathrm{mAhg}^{-1} ; \mathrm{p}_{\text {active }}=2,25 \mathrm{gcm}^{-3} \\
\mathrm{a}_{\mathrm{p}}=3 \% ; \mathrm{u}_{\mathrm{k}}=0,1 \mathrm{~V} ; \\
\mathrm{p}_{\mathrm{e}}=30 \%\end{array}$ \\
\hline Si-Composite $^{1}$ & $12,26 \mathrm{EURkg}^{-1}$ & $\begin{array}{c}\mathrm{c}=1000 \mathrm{mAhg}^{-1} ; \mathrm{p}_{\text {active }}=1,98 \mathrm{gcm}^{-3} \\
\mathrm{a}_{\mathrm{p}}=9 \% ; \mathrm{u}_{\mathrm{k}}=0,35 \mathrm{~V} ; \\
\mathrm{p}_{\mathrm{e}}=40 \%\end{array}$ \\
\hline Cu-Collector & $0,79 \mathrm{EURm}^{-2}$ & \\
\hline Al-Collector & $0,26 \mathrm{EURm}^{-2}$ & \\
\hline Separator & $1,26 \mathrm{EURm}^{-2}$ & \\
\hline Electrolyte & 11,32 EURkg $^{-1}$ & \\
\hline Case & 1,57 EURpcs ${ }^{-1}$ & \\
\hline $\begin{array}{l}\text { Passive } \\
\text { materials }\end{array}$ & 3,52 EUR & $\begin{array}{l}\text { Anode: } p_{\text {passive }}=1,4 \mathrm{gcm}^{-3} \\
\text { Cathode: } p_{\text {passive }}=1,9 \mathrm{gcm}^{-3}\end{array}$ \\
\hline
\end{tabular}

Ex. Rates: EUR/USD 1.47, EUR/JPY 159.52; 1 price estimation

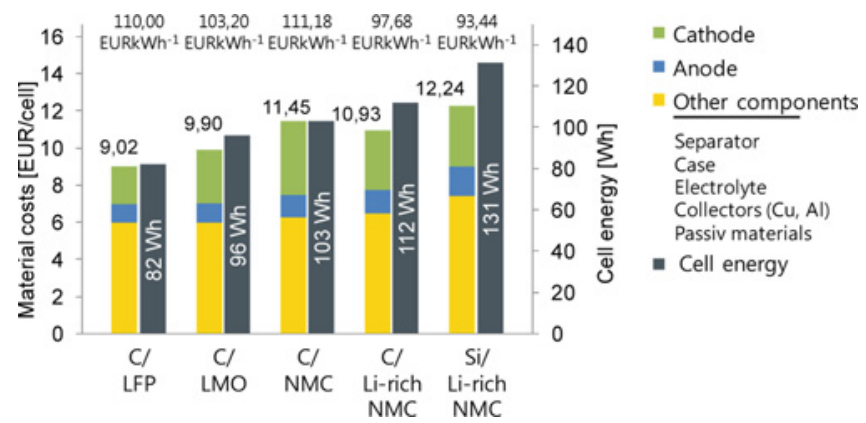

Fig. 5 Results of cell chemical alternatives in a Sanyo PHEV $28 \mathrm{Ah}$ cell current cell chemistries. From a monetary prospective a change of cell chemistry from $\mathrm{C} / \mathrm{NMC}$ to $\mathrm{C} / \mathrm{LMO}$ would make a material cost energy advantage of $8 \mathrm{EURkWh}^{-1}$ possible. Causal for this is the low material cost for the cathode active material LMO. In the future the use of Sicomposite/Li-rich could lead to a reduction of the cost energy ratio relating to the standardized cell chemistry of $18 \mathrm{EURkWh}^{-1}$. Depending on Fig. 5, active material with a high specific energy can definitely help reducing the material cost-energy ratio.

\section{Summary}

This paper shows the advantages of the developed model when assessing cell chemistry alternatives. The model offers thereby a good forecasting quality and especially a very good effort/effectiveness' relationship.

Innovative cell chemistries like for example Si-composite/Li-rich NMC can definitely influence the material cost energy relation positively through the higher specific energy of the active material within the frame of the application. Further the influence on the other material cost blocks during the cell chemistry exchange can be shown. Innovative cell chemistries with a good cost-energy ratio can therefore be the key to reducing material cost respective to the original costs of the li-ion battery and support the implementation of the electric mobility.

\section{ACKNOWLEDGEMENT}

This research was supported by Volkswagen Research Lab China a division of VOLKSWAGEN AG and managed by Dr. Tobias Giebel and Dr. Bin Zhang.

\section{REFERENCES}

1. Herrmann, C., Kieckhäfer, K., Mennenga, M., Skerlos, S., Spengler, T. S., et al., "A Framework to Analyze the Reduction Potential of Life Cycle Carbon Dioxide Emissions of Passenger Cars," in: Leveraging Technology for a Sustainable World, Dornfeld, D. A. and Linke, B. S., (Eds.), Springer, pp. 55-60, 2012.

2. Choi, J., Jeong, J., Park, Y.-I., and Cha, S. W., "Evaluation of Regenerative Braking Effect for E-REV Bus according to Characteristic of Driving Cycle,” Int. J. Precis. Eng. Manuf.-Green Tech., Vol. 2, No. 2, pp. 149-155, 2015.

3. Matthies, G., Stricker, K., and Traenckner, J., "Zum E-Auto Gibt Es Keine Alternative," Bain \& Company, 2010.

4. Institute of Information Technology, Ltd., "LIB Cell Materials Market Bulletin (07Q1)," 2007.

5. Institute of Information Technology, Ltd., "Introduction: The Start of the "LIB-Related Study Program 10-11"," 2010.

6. Institute of Information Technology, Ltd., "LIB Cell Materials Market Bulletin (11Q1)," 2011. 
7. Takeshita, H., "Worldwide Market Update on NiMH, Li Ion and Polymer Batteries for Portable Applications and HEVS," Proc. of the $22^{\text {nd }}$ International Battery Seminar and Exhibit, 2004.

8. Funke, S., "Angebotskalkulation bei Einzelfertigung," Controlling, Vol. 7, No. 2, pp. 82-89, 1995.

9. Günther, T. and Schuh, H., "Näherungsverfahren für Die Frühzeitig Kalkulation von Produkt- und Auftragskosten," Kostenrechnungspraxis, Vol. 42, No. 6, pp. 381-389, 1998.

10. Werhahn, J., "Kosten von B Rennstoffzellensystemen auf Massenbasis in Abhängigkeit von der Absatzmenge,” Forschungszentrum Jülich, 2009.

11. Gaines, L. and Cuenca, R., "Costs of Lithium-Ion Batteries for Vehicles," Transportation, 2000.

12. Amirault, J., Chien, J., Garg, S., Gibbons, D., Ross, B., et al., "The Electric Vehicle Battery Landscape: Opportunities and Challenges," University of California, 2009.

13. Nelson, P. A., Gallagher, K. G., Bloom, I., and Dees, D. W., "Modeling the Performance and Cost of Lithium-Ion Batteries for Electric-Drive Vehicles," Argonne, National Laboratory, 2012.

14. Gallagher, K. G., Dees, D., and Nelson, P., "PHEV Battery Cost Assessment,” DOE Annual Merit Review, 2011.

15. Moon, J., Cho, K., and Cho, M., "Ab-Initio Study of Silicon and Tin as a Negative Electrode Materials for Lithium-Ion Batteries,” Int. J. Precis. Eng. Manuf., Vol. 13, No. 7, pp. 1191-1197, 2012.

16. Barnett, B., Rempel, J., McCoy, C., Dalton-Castor, S., and Sriramulu, S., "PHEV and LEESS Battery Cost Assessment," DOE Annual Merit Review, 2010.

17. Eberman, K., Gomadam, P., Jain, G., and Scott, E., "Material and Design Options for Avoiding Lithium Plating during Charging," ECS Transactions, Vol. 25, No. 35, pp. 47-58, 2010.

18. Wilka, M., Axmann, P., Homann, A., and Wohlfahrt-Mehrens, M., "Inuence of Anode/Cathode Balancing on the Cycling Stability of Lithium Ion Cells," February, 2013.

19. Amperex Technology Limited, "Competitors' Comparison of Reverse Engineering 18650PC,” 2007.

20. Petri, R., "Technologiebasiertes Materialkostenmodell für Innovative Li-Ionen Batteriezellen in der Elektromobilität," Ph.D. Thesis, Institut für Werkzeugmaschinen und Fertigungstechnik, University of Technology Braunschweig, 2015.

21. Arago, O., "Eine Methode zur Abschätzung der Produktionskostenbezogenen Langfristigen Planungsziele Ziviler Turbougtriebwerke," Institut für Luftfahrtantriebe, Ph.D. Thesis, University Stuttgart, 2011.

22. Zhang, J.-G. and Liu, J., "Development of Si-Based High Capacity Anodes," Pacific Northwest, National Laboratory, 2013.

23. Kim, J.-H., Greszler, T., Wenbin, G., Mathias, M., and Sinha, P., "Reaching the Automotive Advanced Lithium-Ion Battery Frontier," Proc. of the $16^{\text {th }}$ International Meeting on Lithium Batteries, 2012.
24. Bernhart, W. and Kruger, F. J., "Technology \& Market Drivers for Stationary and Automotive Battery Systems," Roland Berger, 2012.

25. Kumta, P. N., "Novel Lithium Ion Anode Structures: Overview of New DOE BATT Anode Projects," U.S. DOE Hydrogen Program and Vehicle Technologies Program Annual Merit Review and Peer Evaluation Meeting, 2011.

26. Thurston, A., "Process for Low Cost Domestic Production of LIB Cathode Materials: Project ID \# ES013," The Chemical Company, 2010.

27. Manthiram, A., "Materials Challenges and Opportunities of Lithium Ion Batteries," The Journal of Physical Chemistry Letters, Vol. 2, No. 3, pp. 176-184, 2011.

28. Industrial Economics and Knowledge, "Observe the 2013 International Lithium Battery Positive and Negative Materials Market and Industry Development," Yano Research Institute Ltd., 2013. 